\title{
Impact of sea level rise and shoreline changes in the tropical island ecosystem of Andaman and Nicobar region, India
}

mageswaran thangaraj ( $\nabla$ magesh.presidency@gmail.com )

University of Madras

Sachithanandam V

NCSCM: National Centre for Sustainable Coastal Management

Sridhar R

NCSCM: National Centre for Sustainable Coastal Management

Manik Mahapatra

NCSCM: National Centre for Sustainable Coastal Management

R Purvaja

NCSCM: National Centre for Sustainable Coastal Management

R Ramesh

NCSCM: National Centre for Sustainable Coastal Management

\section{Research Article}

Keywords: Sea level rise, Shoreline changes, Remote Sensing, GIS, Andaman and Nicobar islands

Posted Date: June 4th, 2021

DOl: https://doi.org/10.21203/rs.3.rs-245124/v1

License: (a) (1) This work is licensed under a Creative Commons Attribution 4.0 International License. Read Full License

Version of Record: A version of this preprint was published at Natural Hazards on July 7th, 2021. See the published version at https://doi.org/10.1007/s11069-021-04895-3. 


\section{Abstract}

We report here a four decades of shoreline changes and possible sea level rise (SLR) impact on landuse/landcover (LULC) in Little Andaman Island by using remote sensing (RS) and GIS techniques. A total of six remote sensing data sets covering years between 1976 and 2018 were used to understand the shoreline changes. Moreover, a Digital Shoreline Analysis System (DSAS) was used to estimate short- and long- term shoreline changes from ArcGIS environment. Besides, the Island vulnerability due to SLR was studied through using digital elevation model (DEM). As a result of Sumatra earthquake (2004), the results were showed a significant variation in shorline upliftment and subsidence. The land subsidence was noticed in the range of 1042-3077 ha with sea level rise between 1 and $5 \mathrm{~m}$. Hence, we conclude that Little Andaman Island is vulnerable to SLR and overwhelm low elvation coastal zone.

\section{Introduction}

Coastal zone is a transition area between land and sea, it signifies a relatively small area with extremely productive and diverse ecosystems (Maselli 2004). Moreover, it is very important economic zone due to rich natural resources and $10 \%$ of worldwide population reside with in $10 \mathrm{~m}$ low elevation area (Jiang et al. 2016; McGrananhan et al. 2007). Besides, anthropogenic activities from this population are leads to oceanic pollution, global warming and climate change. The climate change can cause increase of seasurface temperature, sea level rising, larger variability in rainfall pattern and intensity of storm (IPCC 2007; Thornton et al. 2014). According to a report by IPCC, the global average of SLR was $3.2 \mathrm{~mm}_{\text {year }}{ }^{-1}$ during 1993 and 2010. However, the SLR will not be stable across global during the $21^{\text {st }}$ century and will remain increase in future years (Jayanthi et al. 2017). According to small island developing states (SIDS), the small islands nations are most vulnerable to climatic change. Which impacts resulting in limited freshwater and land availability, food scarcity and energy stocks (Schwerdtner Mánez et al. 2012; Borges et al. 2014). The SLR threatens were happened in various small island nations such as Tuvalu and Maldives, which were relatively flat and even less than 2 $m$ elevation from the mean sea level (Brown 2001). Several works reported that the impact of disasters on small islands were more vulnerable than non-island nations (Meheux et al. 2007). The increase of ocean surface temperature may impact sevearly on coral reef ecosystem and associated flora and fauna diversity (Mondal et al. 2014). Besides, the contribution of greenhouse gas from islands are insignificant to global climate change (Mimura 1999), they bear the maximum bur get affected severely form the natural disasters.

An increase of $1 \mathrm{~m}$ sea level in Indian coast results in loss of 5764 sq.km land with displacement of seven million people (MoEF 2009). The 2004 Sumatra earthquake and subsequent tsunami resulted in unprecedented loss of life, property damage and morphological changes in the coastal zones of Indian Ocean rim countries (Ramachandran et al. 2005; Choowong et al. 2009; Paris et al. 2009; Meilianda et al. 2010). Besides, the Andaman and Nicobar Islands (ANI) of India was significantly damaged by the earthquake and subsequent tsunami (Ramanamurthy et al. 2005). The damage include land uplift, subsidence, destruction of coral reef, beach erosion, sediment transport deposition, damage of dunes and mangroves (Nirupama et al. 2006; Dharanirajan et al. 2007; Bahuguna et al. 2008; Prerna et al. 2014; Mageswaran et al. 2015). The geomorphic changes in ANI was studied by using pre \& post-earthquake remote sensing datas and quantified their areal extents (Narayana, 2011). In addition, the subsidence and emergence of North and Middle Andaman districts were reported from South Andaman group of Islands (Rajendran et al. 2007). Recent study from Cuddalore coast of India was reported that around $16.08 \mathrm{~km}^{2}$ area of geomorphological features and $17.5 \mathrm{~km}^{2}$ of LU/LC are expected to be affected in future years (Dhanalakshmi et al., 2019). However, the impacts of SLR and shoreline changes in the coastal area of ANI is not been studied in detailed. Hence, we made an attamept to estimate the potential impacts of SLR in the coastal area of ANI and its historical shoreline changes by using geospatial techniques.

\section{Study area}

Little Andaman is the southernmost and fourth largest island ( $10^{\circ} 30^{\prime}$ to $10^{\circ} 54^{\prime} \mathrm{N}$ and $92^{\circ} 29^{\prime}$ to $92^{\circ} 31^{\prime} \mathrm{E}$ ) among the Andaman group Islands (Fig. 1). This island covers a coastline area of $110 \mathrm{~km}$ with its aerial extent of 734 sq.km. Accroding to Indian census 2011 , the total population of the island was 18,823 which include 16 inhabited villages consists of 4 gram panchayats and residence of Onge aboriginal tribe. Moreover, this island is being consider as tribal rerve area since 1957. The topography of this island is highly undulating with the highest elevation of $210 \mathrm{~m}$ in the central region, where the north and northwestern portions show lesser elevation (0-12 $\mathrm{m})$. The island is consist of ecologically sensitive ecosystems such as mangrove, coral reef, sand dune, sandy beach and turtle nesting sites. The tourist attractions of this island include White Surf \& Whisper Wave waterfalls, Palm oil plantation, Bala reef, Netaji Nagar, Butler Bay beach and dams in Ramakrishnapur and Vivekanandpur are significantly important. Besides, Hut Bay and Dugong 
Creek are the two main Ports of Little Andaman island. According to the Government of India (Ministry of Home Affairs 2005), this island was significantly affected by the 2004 tsunami and claims a death toll up to 37 people.

\section{Materials And Methods}

\section{Data}

In the present study, Landsat imagery of different periods from United State Geological Survey (USGS) were obtained and utilized to study shoreline changes. Besides, the Google earth imagery (digital globe) 2018 was used to update the LULC features. For land elvation, Shuttle Radar Topographic Mission (SRTM) data of $90 \mathrm{~m}$ resolution was downloaded from www.earthexplorer.usgs.gov website and Survey of India Toposheet of 1:50,000 scale was used to extract the topographic contours to create a DEM (Table 1).

\section{Methods}

\section{Shoreline Change Mapping}

The multi-temporal satellite data's are frequently used to extract shorelines from different periods (Umit Duru 2017). Initially, the 2004 satellite image was rectified using 20 Ground Control Points (GPS) collected randomly in the field by using Trimble handheld GPS. Then, the other set of images were geocoded using image to image rectification method and projected all the images to UTM Zone $46 \mathrm{~N}$ and WGS84 Datum by using ERDAS imagine software.

In this study, we have adopted the wet-dry boundary as shoreline and using visual interpretation technique, shorelines were manually digitized in ArcGIS 10.2.1 software for different periods. The extracted shorelines of different periods were fed into Digital Shoreline Analysis System (DSAS) to estimate the change rate. The DSAS is a freely available software, which runs as an additional tool within ArcGIS software and calculates statistical methods using various shorelines. Moreover, the DSAS generates transects lines perpendicular to the shoreline with the transect spacing and length are set at $100 \mathrm{~m}$ and $1 \mathrm{~km}$ respectively (Fig. 2).

A Total of 1285 transect was built to estimate the erosion/accretion rates along the study area. However, three methods were used to estimate the rate of shoreline changes viz., End Point Rate (EPR), Linear Regression Rate (LRR) and Weighted Linear Regression (WLR). In EPR method, the change rate is estimated by the time elapsed between the oldest and the youngest shoreline positions. Whereas in LRR method, the rate of change was calculated by fitting a least-squares regression to all shoreline points for particular transects (Thieler et al. 2003). The advantage of LRR method includes, all shoreline data's can be taken into consideration, easy to employ, irrespective of changes in trend or accuracy, and estimates the variations based on proven statistical concepts (To and Thao 2008). The WLR technique uses a linear regression, considering the account weight of uncertainty errors to determine a best-fit regression line (Fletcher et al. 2012). Based on the results obtained from the DSAS, the shoreline is classified into three classes, i.e. erosion $(<-1)$, stable $(-1$ to +1$)$ and accretion $(>+1)$.

\section{Land use and Land Cover Mapping}

The Landsat- ETM + (2018 image) was used to prepare the land use/land cover (LULC) map. Though, the landsat image is orthorectified, the satellite was geometrically corrected by ERDAS IMAGINE software with available ground control points (GCP) which were collected randomly by using Trimble handheld GPS.

The satellite image was projected to UTM Zone $46 \mathrm{~N}$ and Datum WGS84. The False Color Composite (FCC) was applied in the satellite image to classify the features. Then using visual interpretation technique, the features were manually digitized based on the visual interpretation keys in ArcGIS software and LULC map was prepared. Futher, it was updated with the recent (2018) google earth imagery. A field verification was carried out with help of handheld GPS for checking accuracy of the generated LULC map, and modifications were made accordingly.

\section{Inundation Mapping}

The most apparent effect of SLR is the everlasting inundation of coastal region. The inundation is refers to the gradual submersion of the low-lying coastal lands by sea waters. In this study, we created a DEM by using Shuttle Radar Topographic Mission (SRTM) data and Survey of India's topographic contours. Besides, the SRTM image was used for a spatial resolution of $90 \mathrm{~m}$, with horizontal and vertical accuracies of less than $45 \mathrm{~m}$ and $15 \mathrm{~m}$ respectively, and the relative accuracy to the coastline was less than $1 \mathrm{~m}$ (Demirkesen 
et al., 2008). However, the both the data sets were having different resolution, therefore we applied Krigging interpolation method to merge the data in ArcGIS for producing a seamless topographic DEM. In addition, the DEM data was used to generate three different inundation scenarios (viz., $1 \mathrm{~m}, 3 \mathrm{~m}$ and $5 \mathrm{~m}$ ) through the spatial analyst tool in ArcGIS software. As a result, we could assessed the areas of submergence easily and the impact of projected SLR by overlaying three different inundation scenarios on LULC map.

\section{Results And Discussion}

\section{Assessment of short-term shoreline changes}

In the present study, the EPR method was used in DSAS for assessment of short-term shoreline change covering three different periods such as 1976-2004; 2004-2005 and 2005-2018. During the period 1976 to 2004, the shoreline migration change rate was varied from -8.8 to $7.7 \mathrm{~m} / \mathrm{yr}$ and the average rate was $-0.27 \mathrm{~m} / \mathrm{year}$ (Fig. 3a). The average shoreline change rate in eroding coast was $-2.8 \mathrm{~m} / \mathrm{yr}$ and in the accreting coast, the change rate is $2.42 \mathrm{~m} / \mathrm{yr}$ (table 2). Moreover, the majority of the coastal areas showed a stable coast (58.4 $\mathrm{km})$ followed by erosion $(39 \mathrm{~km})$ and accreting $(31.1 \mathrm{~km}$; table 3$)$. These results indicate that erosion was recorded in the coast of Hut Bay and south of Onge Tikry Island (Fig. 4a).

The morphological changes due to 2004 earthquake in the coastal area was studied by using pre (2004) and post (2005) earthquake satellite images. The results showed that around $27.6 \%$ eroded coast, $3.5 \%$ stable coast and $68.9 \%$ accreting coast (Fig. 5). The erosion was recorded along Dugong Creek, Vivekanandpur, Hut Bay and South Bay (Fig. 4a). The improved accretion areas are due the $26^{\text {th }}$ December 2004 earthquake event, which resulted in upliftment of the western side of Andaman. The graphical shoreline changes for the period 2004-2005 is shown in the figure $3 b$.

Meltzner et al. (2006) analysed the pre \& post satellite images and a tidal model for mapping the 2004 earthquake associated extent upliftment and subsidence in ANI. They found that the southern and eastern areas were gone down, whereas the northern and western Andaman Islands were uplifted. Besides, they reported that islands falling on the east of the pivot lines were subsided and the western side was uplifted. Moreover, Bilham et al. (2005) studied the impact of 2004 earthquake by using aerial photograph of ANI and reported that the northwest coast of the North Sentinel island was actually uplifted in range of 1-2 m.

The morphological changes in Trinkat Island was studied by Yunus and Narayana (2015), the images of pre-tsunami and posttsunami showed that $2.31 \mathrm{sq} . \mathrm{km}$ of the land area got submerged. This result showed that the island is dynamic after the tsunami and around 464 ha of beach area got lost during the period of 2004-2013. During 2005 to 2018, the majority of the coastal areas showed accretion around $42.6 \%$ and erosion in the range of $24.6 \%$ (Fig. 3c). The stable coastal area was noticed over $42.2 \mathrm{~km}$, which was $32.8 \%$ of the total shoreline (Fig. 5). The average accretion was $4.2 \mathrm{~m} / \mathrm{yr}$ and erosion was $-3.7 \mathrm{~m} / \mathrm{yr}$, the major erosion was noticed between the north of Jackson Creek and Apl island, and south of West Bay and Sandy point (Fig. 4a, table 2).

\section{Assessment of long-term shoreline changes}

The long-term shoreline change rate for 42 years (1976 to 2018) was studied by using LRR and WLR methods (Fig. 4b). The LRR method change rate was varied from -5.5 to $23 \mathrm{~m} / \mathrm{yr}$ and erosion and accretion were found in the rate of $12.9 \%$ and was $58.3 \%$ respectively. The stable coast was recorded in $28.8 \%$ of the coast and exhibited with 370 transects. The average shoreline change rate in the eroding coast was $-2.6 \mathrm{~m} / \mathrm{yr}$ and in the accreting coasts was $5.1 \mathrm{~m} / \mathrm{yr}$. (Fig. 3d; table 2; Fig. 5; table 3). Through WLR method, accretion was recorded along $60.3 \%$ of the coast, while the stable and eroding coast reported were $29.8 \%$ and $9.9 \%$ respectively (Fig. 5). The average shoreline change rate in the eroding coast was $-2.2 \mathrm{~m} / \mathrm{yr}$ and accreting coasts was $5.9 \mathrm{~m} / \mathrm{yr}$. The overall mean change rate $(3.3 \mathrm{~m} / \mathrm{yr})$ obtained by WLR was higher than the average change rate of LRR ( $2.6 \mathrm{~m} / \mathrm{yr})$ method (table 2$)$. In general, the long-term shoreline changes showed more accretion than erosion (Fig. 4b)

Malik and Murty (2005) were studied the pre and post-earthquake water levels in Diglipur and Mayabunder jetties, the results showed that the Andaman Islands were vertically uplifted by $1.2 \mathrm{~m}$. Whereas, island got submerged around 2.5-3.0 m in Great Nicobar Island (Malik et al., 2006). Chini et al. (2008) used Synthetic Aperture Radar (SAR) images to identify the upliftment of the entire west coast of Little Andaman. Anu and Rajendran (2006) used GPS measurements to measure the upliftment/subsidence along ANI and found that Little Andaman island and north-eastern part of Andaman Island was uplifted to $36 \mathrm{~cm}$ and $63 \mathrm{~cm}$ respectively, whereas Port Blair was subsided to $87 \mathrm{~cm}$. Yunus et al. (2016) reported that the landform changes in the Katchal Island and its western part is constantly eroding at a lower rate even after 10 years of 2004 earthquake event and it could be due to strong wave and tidal currents prevailing in monsoon periods. The beach recovery in Banda Aceh was noticed after six months of tsunami event. An accretion in the western and 
beach loss in the north-west coast were noticed. Whereas the Phang-nga beach was recovered completely within 2 years from the tsunami event (Meilianda et al. 2010; Choowong et al. 2009). However, Thailand coast was not restored to its original form due to natural erosion and anthropogenic activities (Szczuciński 2012). The shoreline changes in the Little Andaman was connected to natural factors such as waves, tidal action, long-and cross-shore currents, tsunami and storm surges. The newly constructed jetty and breakwater (after tsunami) in Hut Bay Island were leads to a negative impact on coastal morphology (Roy 2017). Besides, the construction of dams at Vivekanandpur and Ramakrishnapur caused less supply of sediment to the coast and drawn in shoreline configuration.

The shoreline variations are associated with repeated cyclonic storms, the SLR and disturb with shore sediment transport by human activities such as harbours, groins or breakwaters are obstruct to natural sediment movement and reducing the sediment deposit in the coast (Morton; 2008). The satellite image were showed that fringing reefs were very limited at eastern side and few patches in western side of Little Andaman. Earlier studies on coral reef suggest that declining in coral covering area in ANI was triggered owing to tsunami waves in 2004, and coral bleaching events were documented during 2005, 2009, 2010, 2012 (Mondal et al. 2013; Dam-Roy et al. 2014). The decline in coral cover area is directly increases the erosion in the coast by invading strong waves. Besides, illegal sand mining in the coastal area also may affect the coastal morphology (Cherian et al., 2012).

\section{Estimation of land use and land cover (LULC)}

The LULC map for Little Andaman was derived from the Google Earth imagery (2018) and categorized into 13 classes with aerial extent (Fig. 6; table 4). The reserve forest was covered a largest component of LULC, which covered 58414.28 ha (79.64\%) followed by mangroves 3933.43 ha (5.36\%), settlement with vegetation 3220.6 ha (4.39\%), and plantation 2111.31 ha (2.88\%; table 4). In previous study, nearly 237.13 ha of reserve forest was reported as lost due to 2004 tsunami and further reduced to 681 ha between 2003 and 2010 due to expansion of settlements area (Dharanirajan eta al., 2013). However, recent study reported that the forest cover reduced from 623.65 sq.km (1976) to 593 sq.km (2017) and most prominent changes were noticed after the tsunami (Mahapatra et al., 2019). The mangroves of Little Andaman were found along creeks and intertidal mudflats in the north-east and north-western parts of this island, especially in Jackson creek, Dugong creek and Bumila creek (Fig. 6). The present study estimated that mangrove covering area was 4130 ha during 2018 and the Rhizophora and Bruguiera species were the dominant species in the Little Andaman island. Due to tsunami, around 3400 ha of mangrove area was submerged, 1700 ha and 140 ha were damaged and degraded respectively (Shankar et al., 2013). After the tsunami, around 1973 permanent shelters were constructed in Little Andaman (Hut Bay and Netaji Nagar) with the help of Government and NGO'S (http://www.and.nic.in/shelterP/islandwise.htm). Besides, a large numbers of infrastructure set up were brought in to this island. which includes community buildings (community hall, health sub-center, schools etc), sanitary systems and road network.

However, some infrastructures and tsunami houses were expanded with deforestation of reserve forest in some locations. From the literature study, we understand that settlement with vegetation is increased gradually due to increasing population and associated infrastructural development, establishment of permanent tsunami shelter and tourism development. Plantation in Little Andaman was estimated as 2111.31 ha (2.88\%) in 2018 and agriculture is the backbone for local people in this island, despite tourism and fishing activities. The important agricultural crops are paddy, vegetables, coconut, arecanut, red oil palm, pulses, and fruits. In 1979, the Government of India sanctioned a project for raising 2,400 ha of Red Oil Palm Project in this island and under this programme, around 1593 ha was allocated for plantation within the reserve forest area. A report by Environment and Forests stated that the plantation in Little Andaman was carried within the reserve forest area in some places, which also could be a reason for the reduction in the forest cover (Department of Environment and Forests, Andaman and Nicobar Islands, 2011).

Coral reef of Little Andaman exhibits narrow, linear and extensively well-developed fringing reefs in all around the island, except at Hut bay, West bay and Jackson creek (Fig. 6). The area covers around 3621.29 ha (4.9\%) and comprises three important coral genera are Acropora spp., Psammocora spp. and Goniastrea sp. According to Coastal Ocean Research and Development in the Indian Ocean status report (CORDIO 2008), an estimate of $12.85 \mathrm{sq} . \mathrm{km}$ of reef area was damaged in Little Andaman due to the 2004 tsunami. The island hosts white sandy beaches in Butler Bay, Hut Bay, Harminder bay, John Richardson Bay, South Bay, West Bay and Ekiti Bay which covers an area of 351.91 ha (0.4\%). The Butler Bay and Hut Bay beaches of Little Andaman serve as tourist hotspots. The sandy beaches of Little Andaman also host nesting of turtles and the major turtle species of this island includes Hawksbill, Green, Olive ridley and Leatherback. The nesting site of Green turtle's is more than other turtle's, which was reported in West Bay, South Bay, north of Hut

Bay, Butler Bay, south of Bumila Creek, north and south of Jackson Creek, (Andrews and Tripathy 2004). The field photographs of LULC and coastal features of Little Andaman were shown in figures 7 \& 8. 


\section{Estimation of inundation due to SLR}

Three different inundation scenarios i.e., $1 \mathrm{~m}, 3 \mathrm{~m}$ and $5 \mathrm{~m}$ were generated using the spatial analyst tool in ArcGIS software (Fig. 9). The projected SLR impact on LULC showed the level of inundation and the type of LULC to be affected (table 4). If the sea level rises around $1 \mathrm{~m}$, submerge may take place in an area of 1042 ha. Likewise, $3 \mathrm{~m}$ and $5 \mathrm{~m}$ rise may cause submerge around 2049 ha and 3077 ha respectively. Under the $1 \mathrm{~m}$ SLR scenario, this study results show that some areas such as reserve forest (831.908 ha), degraded forest (192.7 ha), settlement with vegetation (10.7 ha), scrub land (5.7 ha) and plantation (1.7 ha) areas may submerged (table 4). Similarly, $5 \mathrm{~m}$ SLR scenario may cause submerge of reserve forest largely with an aerial coverage of 2576 ha, followed by degraded forest (336.64 ha), settlement with vegetation (72.3 ha), plantation (29.19 ha) and scrub land (23 ha). A related study from Andhra coast reported that rise of $0.6 \mathrm{~m} \mathrm{SLR}$ may displace more than 1.29 million people from the coast. Moroevoer, the study mapped and categriesed very high-risk areas such as mudflats, mangrove swamps and backwaters of Krishna, Godavari and Penner deltaic region (Rao et al., 2008). In the vulnerability point of view, coastal slope plays an important role in determining the extent of inundation for any coastal hazards (Dinesh Kumar; 2006). The effect of SLR would be significant to a low-lying coast and conflicting to steeply sloping coast (Mani-Murali et al. 2013). During 2004 tsunami, the maximum inundation was taken place at Akkaraipettai (Nagapattinam district, Tamil Nadu) which was due to the low-lying and gently sloping topography (Ramanamurthy et al. 2005). However, the high elevated and steep sloping coast of Kanyakumari and Kadiapattinam (south Tamil Nadu) were experienced only less inundation (Chandrasekar et al. 2007).

Three primary coastal features of the present study area viz., reserve forest, settlements with vegetation, plantation suffers the maximum damage of inundation due to rising sea level. The major forest types in the study area includes Andaman Tropical Evergreen, Andaman Semi-evergreen, Andaman Moist Deciduous and Littoral forests (Champion and Seth 1968). From this study, we found that around 1024 ha (44.84\%) of forest land (includes both degraded forest \& reserve forest) would be submerged due to $1 \mathrm{~m}$ SLR and for 3 and $5 \mathrm{~m}$ rise, the submergence would be 1988.4 ha (68.6\%) and 2912.7 ha (80.26\%) respectively. The littoral forests (reserve forest) would be under severe threat of inundation due to $1 \mathrm{~m}$ and $5 \mathrm{~m} \mathrm{SLR}$, which covers between 150-200 $\mathrm{m}$ from the seashore and are mostly dominated by endemic trees Manilkara littoralis, Terminalia catappa, Gyrocarpus americanus, Guettarda speciosa and Pongamia pinnata (Rasingam and Parathasarathy 2009). The coastal forest act as a defencing mechanism to reduce the impact of tsunami and storm surges (Yanagisawa et al. 2009). During 2004 tsunami, the dense coastal vegetation reduced the height of the tsunami wave, whereas the absence of coastal forests caused the highest level of damage (Shuto 1987; Danielsen et al. 2005). The Settlements with vegetation (LULC category) in Little Andaman island experience the second largest damage by the projected SLR. The settlements area is spread across five revenue villages of Little Andaman viz., Vivekanda Pur, Rabindra Nagar, Ram Krishna Pur, Netaji Nagar and Hut Bay. Among this, Netaji Nagar and Hut Bay located in the southeast of Little Andaman, which are highly vulnerable to SLR due to the gentle slope, low-lying coastal topography and population density. The settlements with vegetation category's inundation to $1 \mathrm{~m}$ SLR is about 10.72 ha and for $3 \mathrm{~m}$ and $5 \mathrm{~m}$ SLR is 37.98 ha and 72.38 ha respectively. The Tsunami houses in Little Andaman are constructed at higher elevation (around $10 \mathrm{~m}$ ) and located $1 \mathrm{~km}$ away from the coast, which show the safety and free from coastal hazards. Plantation in Little Andaman also have a considerable damage due to SLR, around 1.72 ha $(0.08 \%)$, of land would be susceptible to $1 \mathrm{~m}$ SLR. Whereas 3 and $5 \mathrm{~m}$ rise, around 8.25 ha $(0.39 \%)$ and 29.19 ha (1.38\%) would be submerged respectively. From the field survey, we noticed arecanut plantation in Vivakanand Pur and Rabindra nagar villages. Besides, coconut plantation are noticed in Hut bay area (south).

The Rhizophora and Bruguiera species are the two dominant mangrove species in the Little Andaman. The SLR may have significant adverse effect on mangroves and it could alter to SLR to a certain degree by expanding landwards or seawards (Spalding et al. 2014). However, it does not survive in less rate of sediment formation than the rate of SLR (Gilman et al. 2008). The impact of SLR on mangrove ecosystems is based on the substrate type, marine processes, local tectonics, sediment and freshwater availability and salinity of soil and groundwater (Semeniuk 1994; Blasco et al. 1996). The SLR is expected to reduce the mangrove coverage and decrease in species diversity on small islands with micro-tidal sediment-limited environments (Raha et al. 2012). Coral reefs are highly sensitive and are particularly susceptible to SLR due to minor changes in environmental conditions. A slight increase in sea temperature (as little as $1-2^{\circ} \mathrm{C}$ ) can cause stress and leads to coral bleaching (Dodge et al. 2008). A large scale destruction of coral reef in ANI was noticed due to tectonic activity and subsequent tsunami event (Kulkarni et al. 2008). Moreover, many bleaching events were reported from the Andaman Sea due to increase of surface temperature in the years of 1991, 1995, 1997, 1998 and 2010 (Mondal et al. 2013). Previous study reported that around 80\% bleeching occurred in Andamn coral reefs in the year 1998 (Pet-Soede et al. 2000). The loss of coral reefs indirectly affect the socio-economic of the coastal communities through fisheries, commercial tourism, recreational opportunities and hazard proneness of the shore. 
Sandy beaches in the Little Andaman are the important tourist destinations and breeding ground for sea turtles. These beaches were severely affected by the 2004 tsunami and later recovered substantially (Swaminathan et al., 2011). The sandy beaches are susceptible to the impact of raising sea level, which results in the vanishing of pristine beaches and subsequently affects the livelihood of the people and the country's economy. Moreover, it also causes loss of turtle breeding site and consequently in decline of turtle population.

\section{Mitigation measures}

The following are some of the mitigation measures to overcome climatic change and SLR impact (modified after Natesan and Parthasarathy 2010).

1. Special attention to the densely populated and low-lying coastal areas.

2. Avoiding new developmental activities near the coast (especially in predicted inundated areas).

3. Relocate the public facilities and infrastructure to safer zones.

4. Shield the highly vulnerable coast by suitable hard structures (jetties, groins or seawalls).

5. Protect the coastal forest by proper monitoring and management.

6. Strengthen the coral reef ecosystem by monitoring and developing new coral reef restoration sites.

7. Protection of coastal sand dunes and its ecosystem.

8. Conserve and protect mangrove forest ecosystem.

9. Creating awareness on SLR and mitigation measures among the government officials and local community.

10. Enhancing the sea level monitoring techniques and develop realistic inundation scenarios.

11. To plan adaptive and risk reduction policies for the sustainable development of the coast.

\section{Conclusion}

We studied the shoreline changes occurred in the past and identified the vulnerable areas to the projected SLR. This shoreline change study shows that 2004 Sumatra earthquake altered the coastal morphology of Little Andaman. The results obtained by LRR and WLR methods were very similar, however, the WLR method takes into account the uncertainty errors. Hence, these two methods can be suggested for the shoreline management plan. Our study indicates that the coastal areas of Little Andaman are susceptible to flooding in various degrees resulting in permanent inundation, episodic flooding, aggravate erosion, seawater intrusion and destruction of important ecosystems (wetlands and forest). Moreover, about 1042 ha of the study area would submerge due to $1 \mathrm{~m}$ SLR, and it would be a slow onset phenomenon. Due to low-lying, gently slope and closeness to the coast, the Hut bay and Netaji Nagar are more susceptible to SLR and other natural hazards (storm surges). The SLR is a potential hazard to these areas in near future and will affect coastal ecosystems and socio-economic. Hence, which demands for protective measures to prevent the losses. This study would be useful to the $A \& N$ administration to draw suitable disaster and mitigation management plans. Besides, this study proves that the combined usage of RS and GIS technique would be useful in monitoring the coastal ecosystem very effectively.

\section{Declarations}

\section{Acknowledgments}

The first author would like to thank the Director, NCSCM for providing support for the research work. This study was undertaken as part of the In-house project "Data Web on Island Environment and Protection". The authors acknowledge the financial and technical support of the Ministry of Environment, Forest and Climate Change, Government of India and the World Bank under the India ICZM Project (P097985).

\section{Ethics approval / statement}

No need for ethics approval, since this work does not include research on identifiable human material or data.

\section{Disclosure statement}

No potential conflict of interest was reported by the all authors. 


\section{References}

Abuodha PA, Woodroffe CD (2006) International assessment of vulnerability of the coastal zone to climatic change, including an Australian perspective. Canberr. Prepared for the Australian Greenhouse Office, Department of Environment and Heritage.

Al-Nasrawi AKM, Hamylton SM, Jones BG, Hopley CA, Al Yazichi YM (2018) Geoinformatics vulnerability predictions of coastal ecosystems to sealevel rise in southeastern Australia. Geomatics Nat Haz and Risk 9:645-661.

Alongi DM (2008) Mangrove forests: Resilience, protection from tsunamis, and responses to global climate change. Estuarine Coast. Shelf Sci. 76 1-13.

Andrews HV, Tripathy A (2004) Tracing the Migrations of Indian Marine Turtles: Towards an Integrated and Collaborative Conservation Program - Andaman and Nicobar Islands. In: Interim report to the Madras Crocodile Bank Trust, CMS / UNEP Project. Centre for Herpetology / Madras Crocodile Bank Trust, India.

Anu R, Rajendran K (2006) Co-seismic deformation along the Andaman-Nicobar arc based on GPS data and ground observations. XVIII Kerala Science Congress, 29-31 January 2006, CESS, Akkulam, Thiruvananthapuram, India, 226-228.

Bahuguna A, Nayak S, Roy D (2008) Impact of the tsunami and earthquake of 26th December 2004 on the vital coastal ecosystems of the Andaman and Nicobar Islands assessed using RESOURCESAT AWiFS data. International Journal of Applied Earth Observation and Geoinformation, 10: 229-237.

Bilham R, Engdahl ER, Feldl N, Satyabala SP (2005) Partial and complete rupture of the Indo-Andaman plate boundary 1847- 2004, Seismol. Res. Lett., 76: 299-311.

Blasco F, Saenger P, Janodet E (1996) Mangroves as indicators of coastal change. Catena 27:167-178.

Borges P, Phillips MR, Ng K, Medeiros A, Calado H (2014) Preliminary coastal vulnerability assessment for Pico Island (Azores). Journal of Coastal Research 70: 385-388.

Brown LR (2001) Rising sea level forcing evacuation of island country. Earth Policy Inst. Available via http://www.earth-policy. org/Updates/Update2.htm. Accessed on 2 Aug 2008.

Calado H, Quintela A, Porteiro J (2007) 'Integrated Coastal Zone Management Strategies on Small Islands', Journal of Coastal Research, SI50:125-129. 
Census of India (2011). Data sheet on rural urban break up of population, Census Directorate, Andaman and Nicobar Islands, Port Blair.9 pp.

Chadha RK, Latha G, Yeh H, Peterson C, Katada T, (2005) The tsunami of the great Sumatra earthquake of M 9.0 on 26 December 2004 - impact on the east coast of India. Current Science 88: 1297-1301.

Chandrasekar N, Immanuel JL, Sahayam JD, Rajamanickam M, Saravanan S (2007) Appraisal of tsunami inundation and run-up along the coast of Kanyakumari District, India-GIS analysis. Oceanologia 49(3):397-412.

Cherian A, Chandrasekar N, Gujar AR, Rajamanickam V (2012) Coastal erosion assessment along the southern Tamilnadu coast, India. Int. J. Earth Sci. and Engg 5(2): 352-357.

Chini M, Bignami C, Stramondo S, Pierdicca N (2008) Uplift and subsidence due to the 26 December 2004 Indonesian earthquake detected by SAR data. International Journal of Remote Sensing 29(13): 3891-3910.

Choowong M, Phantuwongraj S, Charoentitirat T, Chutakositkanon V, Yumuang S, Charusiri P (2009) Beach recovery after 2004 Indian Ocean tsunami from Phang-nga, Thailand. Geomorphology 104(3): 134-142.

CORDIO Status Report (2008) Coastal Oceans Research and Development in the Indian Ocean/Sida-SAREC. Mombasa. http//:www.cordioea.org.

Cozannet GL, Garcina M, Yates M, Idier D, Meyssignac B (2014) Approaches to evaluate the recent impacts of sea-level rise on shoreline changes. Earth Sci Rev 138:47-60.

Dam-Roy S, Grinson G, Soundararajan R, Krishnan P, Murugesan S, Kaliyamoorthy M (2005) Status of coral reefs in Andaman after two major catastrophic events - tsunami of December 2004 and bleaching of May.Eco. Env. \& Cons., 20(2): 539-544.

Danielsen F. et al., (2005) The Asian Tsunami: A Protective Role for Coastal Vegetation. Science 310: 1.

Department of Environment \& Forests, Andaman and Nicobar Islands (2011) Forest Code 2011 http://forest.and.nic.in/ActsNRules\%5CAnNFDC2011.pdf, accessed on 30 June 2016.

Dhanalakshmi S, Kankara RS, Chenthamil Selvan S (2019) Impact assessment of sea level rise over coastal landforms: a case study of Cuddalore coast, south-east coast of India. Environmental Earth Sciences DOI:10.1007/s12665-019-8463-1.

Dharanirajan K, Kasinathapandian P, Gurugnanam B, Narayanan RM, Ramachandran S (2007) An integrated study for the assessment of Tsunami impacts: a case study using remote sensing and GIS. Coast Eng J., 49(3): 229-266. 
Dickson ME (2004) The development of Talus Slopes around Lord Howe Island and Implications for the History of Island Planation. Australian Geographer 35: 223-38.

Dinesh Kumar PK (2006) Potential Vulnerability Implications of Sea Level Rise for The Coastal Zones of Cochin, Southwest Coast of India, Environ. Monit. Assess., 123: 333-344.

Dodge RE, Birkeland C, Hatziolos M, Kleypas J, Palumbi SR, Hoegh-Guldberg O, Van Woesik R, Ogden JC, Aronson R, Causey BD, Staub F (2008) A call to action for coral reefs. Science 322: 189-190.

Fletcher CH, Romine BM, Genz AS, Barbee MM, Dyer M, Anderson TR, Lim SC,Vitousek S, Bochicchio C, Richmond BM (2012) National assessment of shoreline change: Historical shoreline change in the Hawaiian Islands. U.S. Department of the Interior, Open-File Report (2011-1051), Reston, VA: U.S. Geological Survey.

Gilman EL, Ellison J, Duke NC, Field C (2008) Threats to mangroves from climate change and adaptation options: a review. Aquatic Botany 89(2): 237-250.

Hinkel J, et al, (2014) Coastal flood damage and adaptation costs under 21st century sea-level rise. Proceedings of the National Academy of Sciences 111: 3292-3297.

Mondal T, Raghunathan c, Venkataraman K (2014) Coral bleaching in Andaman sea- an indiator for climatic change in Andaman and Nicobar islands. Indian Journal of Geo-Marine Sciences 43: 1945-1948.

IPCC (2007) Climate change 2007: the physical science basis. Summary for policy makers.

IPCC (2013) Summary for policy makers. In Climate Change 2013: The Physical Science Basis; Stocker TF, Qin D, Plattner GK, Tigno M, Allen SK, Boschung J, Nauels A, Xia Y, Bex V, Midgley PM, Eds.; Cambridge University Press: Cambridge, UK.

Jana AB, Hegde AV (2016) GIS based approach for vulnerability assessment of the Karnataka coast, India. Hindawi Publishing Corporation Advances in Civil Engineering 1-10. https://doi.org/10.1155/2016 /5642523.

Jayanthi M, Thirumurthy S, Samynathan M, Duraisamy M, Muralidhar M, Ashokkumar J, Vijayan KK (2017) Shoreline change and potential sea level rise impacts in a climate hazardous location in southeast coast of India. Environmental Monitoring and Assessment, 190(1). doi:10.1007/s10661-017-6426-0. 
Jiang D, Hao M, Fu J (2016) Monitoring the Coastal Environment Using Remote Sensing and GIS Techniques. Applied Studies of Coastal and Marine Environments. doi:10.5772/62242.

Kathiresan K, Rajendran N (2005) Coastal mangrove forests mitigated tsunami. Estuarine, Coastal and Shelf Science 65: 6.

Koroglu A, Ranasinghe R, Jiménez JA, Dastgheib A (2019) Comparison of Coastal Vulnerability Index applications for Barcelona Province. Ocean \& Coastal Management DOI:10.1016/j.ocecoaman.2019.05.001.

Krishnakumar PK, (2008) Climate Change related marine ecosystem regime shifts and their impact on fisheries. Winter School on Impact of Climate Change on Indian Marine Fisheries, CMFRI, 2008.

Kulkarni S, Patankar V, D'souza E (2008) Status of earthquake and tsunmi affected coral reefs in Andaman Nicobar Islands, India. In D Obura, J Tamelander, O Linden (Eds.) Coastal Oceans Research and Development in the Indian Ocean:Status Report 173 - 183.

Mageswaran T, Sachithanandam V, Sridhar R, Ramesh R (2015) Mapping and monitoring of landuse/land cover changes in Neil island (South Andaman) using geospatial approaches. Indian Journal of Geo-Marine Science 44(11): 1762-1768.

Mahapatra M, Sridhar R, Badarees KO (2019) Spatio-temporal analysis of land use and land cover changes in the Little Andaman Island, Andaman, India using geospatial techniques. Journal of Geomatics, 13: 209-216.

Malik JN, Murty CVR (2005) Landscape changes in Andaman and Nicobar Islands (India) due to Mw 9.3 tsunamigenic Sumatra earthquake of 26 December 2004.Current Science 88(9):1384-1386.

Malik JN, Murty CVR, Eeri M, Durgesh C, Rai M (2006) Response and Recovery in India after the December 2004 Great Sumatra Earthquake and Indian Ocean Tsunami. Earthquake Spectra, 22(S3): 43-66.

Mani-Murali R, Ankita M, Amrita S, Vethamony P (2013) Coastal vulnerability assessment of Puducherry coast, India, using the analytical hierarchical process. Natural Hazards and Earth System Sciences, 13(12): 3291-3311. doi:10.5194/nhess-13-3291-2013

Maselli F (2004) Monitoring forest conditions in a protected Mediterranean coastal area by the analysis of multiyear NDVI data. Remote Sensing of Environment 89:423-33.

McGranahan G, Balk D, Anderson B (2007) The rising tide: assessing the risks of climate change and human settlements in low elevation coastal zones. Environment and Urbanization 19(1): 17-37. DOI: 10.1177/0956247807076960. 
Meheux K, Dominey-Howes D, Lloyd K (2007) Natural hazard impacts in small island developing states: A review of current knowledge and future research needs. Natural Hazards 40(2): 429-446.

Meilianda E, Dohmen-Janssen C, Maathuis B, Hulscher S, Mulder J (2010) Short-term morphological responses and developments of Banda Aceh coast, Sumatra island, Indonesia after the tsunami on 26 December 2004. Mar Geol, 275(1): 96-109.

Meltzner AJ, Sieh K, Abrams M, Agnew DC, Hudnut KW, Avouac JP, Natawidjaja DH (2006) Uplift and subsidence associated with the great Aceh-Andaman earthquake of 2004. J Geophys Res., DOI: 10.1029/2005JB003891.

Mimura N (1999) Vulnerability of island countries in the South Pacific to sea level rise and climate change. Climate Research 12: 137143. doi:10.3354/cr012137.

Ministry of Home Affairs (MHA) (2005) Annual Report 2004-2005, MHA, Government of India, New Delhi.

MoEF (2009) State of Environment Report India-2009, Environmental Information System (ENVIS), Ministry of Environment and Forests, Government of India, New Delhi, $97 \mathrm{pp}$.

Mohan VR, Gnanavel D, Sriganesh J, Kulasekaran J, Srinivasalu S (2005) The $26^{\text {th }}$ December, 2004 Tsunami run-up and inundation and their relationship with geomorphology in Tamilnadu, India. Available via DIALOG.http://www.sthjournal.org/tsabst/mohan. pdf\#search=\%22geomorphology\%2Btsunami\%22. Accessed on March 2009s.

Mondal T, Raghunathan C, Venkataraman K (2013) Bleaching: The Driving Force of Scleractinian New Recruitment at Little Andaman Island, Andaman and Nicobar Islands Proc. Natl. Acad. Sci., India, Sect. B: Biol. Sci. DOI 10.1007/s40011-013-0168-8.

Morton RA (2008) Historical changes in the Mississippi-Alabama Barrier-Island chain and the roles of extreme storms, sea level, and human activities. J Coast Res 24:1587-1600. https://doi.org/10.2112/07-0953.1.

Narayana A (2011) Tectonic geomorphology, tsunamis and environmental hazards: reference to Andaman-Nicobar Islands. Nat Hazards 57(1):65-82.

Narayana AC, Tatavarti R, Shinu N, Subeer A (2007) Tsunami of December 26, 2004 on the southwest coast of India: Post-tsunami geomorphic and sediment characteristics. Marine Geology 242(1): 155-168.

Nirupama N, Murty TS, Nistor I, Rao AD (2006) Persistent high water levels around Andaman \& Nicobar Islands following the 26 December 2004 Tsunami. Sci Tsunami Haz 24(3):183-193. 
Paris R, Wassmer P, Sartohadi J, Lavigne F, Barthomeuf B, Desgages E, Grancher D, Baumert P, Vautier F, Brunstein D (2009) Tsunamis as geomorphic crises: Lessons from the December 26, 2004 tsunami in Lhok Nga, west Banda Aceh (Sumatra, Indonesia).

Geomorphology 104(1): 59-72.

Parthasarathy A, Natesan U (2014) Coastal vulnerability assessment: a case study on erosion and coastal change along Tuticorin, Gulf of Mannar. Natural Hazards, 75(2), 1713-1729. doi:10.1007/s11069-014-1394-y.

Pendleton EA, Thieler ER, Williams SJ (2004) Coastal vulnerability assessment of Cape Hettaras National Seashore (CAHA) to sea level rise. USGS Open File Report 2004-1064. Available from http://pubs.usgs.gov/of/2004/1064/images/pdf/caha.pdf accessed on 30 Aug 2008.

Pet-Soede L, Wafar MVM, Venkataraman K, Rajan PT, Wilhelmsson D (2000) The status of the coral reefs of India following the bleaching event of 1998. Coral Reef degradation in the Indian Ocean: Status Report and Project Presentations, 69 -74.

Prerna R, Srinivasa Kumar T, Mahendra RS, Mohanty PC (2014) Assessment of Tsunami Hazard Vulnerability along the coastal environs of Andaman Islands. Natural Hazards, 75(1): 701-726. doi:10.1007/s11069-014-1336-8. s

Raha A, Das S, Banerjee K, Mitra A (2012) Climate change impacts on Indian Sunderbans: a time series analysis (1924-2008). Biodiversity and Conservation, 21(5): 1289-1307. doi:10.1007/s10531-012-0260-z.

Rajendran CP, Rajendran K, Anu R, Earnest A, Machado T, Mohan PM, Freymueller J (2007) Crustal Deformation and Seismic History Associated with the 2004 Indian Ocean Earthquake: A Perspective from the Andaman-Nicobar Islands. Bulletin of the Seismological Society of America, 97(1A): 174-191. DOI:10.1785/0120050630.

Ramachandran S, Anitha S, Balamurugan V, Dharanirajan K, Vendhan KE, Divien MIP, Vel AS, Hussain IS, Udayaraj A (2005). Ecological impact of tsunami on Nicobar Islands (Camorta, Katchal, Nancowry and Trinkat). Curr Sci, 89(1): 195-200.

Ramanamurthy MV, Sunadramoorthy S, Ari Y, Ranga Rao V, Mishra P, Bhar M, Usha T, Venkatesan R, Subramanian BR (2005) Inundation of seawater in Andaman and Nicobar Islands and parts of Tamil Nadu coast during 2004 Sumatra tsunami, Curr. Sci. 88(11): 1736-1740.

Rasingam L, Parathasarathy N (2009) Tree species diversity and population structure across major forest formations and disturbance categories in Little Andaman Island, India. Tropical Ecology, 50(1): 89-102.

Rao NK, Subraelu P, Rao VT, Malini BH, Ratheesh R, Bhattacharya S, Rajawat AS, Ajai (2008) Sea-Level Rise and Coastal Vulnerability: An Assessment of Andhra Pradesh Coast, India through Remote Sensing and GIS. Journal of Coastal Conservation, 12: $195-207$. 
Roy SD (2017) Developmental Strategies and its Impact on an Island's Ecosystem and Bio-diversity: A Geographical Appraisal on Little Andaman Island, Andaman Archipelago, India. XVI World Water Congress, International water resource association, Cancun, Quintana Roo, Mexico.

Roy SD, George G, Soundararajan R, Krishnan P, Murugesan S, Kaliyamoorthy M (2014) Status of coral reefs in Andaman after two major catastrophic events-tsunami of December 2004 and bleaching of May 2005.Ecology Environment and Conservation 20: 539544.

Schwerdtner Mánez K, Husain S, Ferse S, Mánez Costa M (2012) Water scarcity in the Spermonde Archipelago, Sulawesi, Indonesia: past, present and future. Environmental Science \& Policy 23: 74-84.

Semeniuk V (1994) Predicting the effect of sea-level rise on mangroves in Northwestern Australia. Journal of Coastal Research, 10(4), 1050-1076.

Shankar SV, Dharanirajan K, Deepak KA, Manoharan R, Narayanan M, Rajmohan K (2013) Pre and Post Tsunami Changes of Land Use and Land Cover in the Little Andaman Island, India: A Geospatial Approach. International Journal of Earth Sciences and Engineering, 6(1): 80-86.

Shuto N (1987) The effectiveness and limit of tsunami control forests. Coastal Engineering in Japan 30: 143-153.

Siripong A (2006) Andaman Seacoast of Thailand Field Survey after the December 2004 Indian Ocean Tsunami. Earthquake Spectra 22(S3): 187-202.

Spalding M, Mclvor A, Tonneijck FH, Tol S, Van Eijk P (2014) Mangroves for coastal defense:Guidelines for coastal managers and policy makers. University of Cambridge: Wetlands International and the Nature Conservancy.

State of Environment Report India (2009) Ministry of Environment and Forests, Government of India publication, 2009.

Swaminathan A, Namboorthri N, Shanker K (2011) Post-tsunami status of leatherback turtles on Little Andaman Island. Indian Ocean Turtle Newsletter, 1(14), 5-9.

Szczuciński W (2012) The post-depositional changes of the onshore 2004 tsunami deposits on the Andaman Sea coast of Thailand. Nat Hazards 60(1):115-133.

Theiler ER, Martin D, Ergul A (2003) The Digital Shoreline Analysis system, Version 2.0: Shoreline Change Measurement Software Extension for ArcView. 03-76. 
Thieler ER, Hammar-Klose ES (2000) National Assessment of Coastal Vulnerability to

Future Sea-Level Rise: Preliminary Results for the U.S. Pacific Coast: U.S. Geological Survey, Open-File Report 00-178.

Thornton PK, Ericksen PJ, Herrero M, Challinor AJ (2014) Climate variability and vulnerability to climate change: a review. Global Change Biology 20(11): 3313-3328. DOI:10.1111/gcb.12581.

To DV, Thao PTP (2008) A shoreline analysis using DSAS in Nam Dinh coastal area, International Journal of Geoinformatics, 4: p. 3742.

Umit D (2017) Shoreline change assessment using multi-temporal satellite images: a case study of Lake Sapanca, NW Turkey. Environ Monit Assess DOI 10.1007/s10661-017-6112-2.

Natesan U, Parthasarathy A (2010) The potential impacts of sea level rise along the coastal zone of Kanyakumari District in Tamilnadu, India. J Coast Conserv. 14:207-214.

Yanagisawa H, Koshimura S, Goto K, Miyagi T, Imamura F, Ruangrassamee A, Tanavud C (2009) The reduction effects of mangrove forest on a tsunami based on field surveys at Pakarang Cape, Thailand and numerical analysis. Estuarine, Coastal and Shelf Science 81(1): 27-37. DOI:10.1016/j.ecss.2008.10.001.

Yunus AP. Jie D, Ram A, Narayana AC (2016) Shoreline and Coastal Morphological Changes Induced by the 2004 Indian Ocean Tsunami in the Katchal Island, Andaman and Nicobar - A Study Using Archived Satellite Images. V Santiago-Fandiño et al. (eds.), Tsunamis and Earthquakes in Coastal Environments, Coastal Research Library, doi 10.1007/978-3-319-28528-3_5.

Yunus AP, Narayana AC (2015) Short-term morphological and shoreline changes at Trinkat island, Andaman and Nicobar, India, after the 2004 tsunami. Mar Geod 38(1):26-39.

\section{Tables}

Table 1 Details of the data used 


\begin{tabular}{|c|c|c|c|c|c|c|}
\hline S.No & Data type & $\begin{array}{l}\text { Satellite/Map/ } \\
\text { Insitu } \\
\text { measurements }\end{array}$ & $\begin{array}{c}\text { Date of } \\
\text { Acquisition }\end{array}$ & $\begin{array}{l}\text { Spatial } \\
\text { Resolution (m) }\end{array}$ & Source & Purpose \\
\hline \multirow[b]{6}{*}{1} & \multirow[t]{6}{*}{$\begin{array}{l}\text { Remote } \\
\text { Sensing }\end{array}$} & $\begin{array}{l}\text { Landsat- } \\
\text { 8/ ETM+ }\end{array}$ & $30 / 10 / 2018$ & 30 & \multirow[t]{6}{*}{ www.earthexplorer.usgs.gov } & \multirow[t]{6}{*}{$\begin{array}{l}\text { Shoreline } \\
\text { change }\end{array}$} \\
\hline & & Landsat-5/TM & $26 / 02 / 2010$ & 30 & & \\
\hline & & Landsat-5/TM & $20 / 02 / 2005$ & 30 & & \\
\hline & & Landsat-5/TM & $13 / 03 / 2004$ & 30 & & \\
\hline & & Landsat-5/TM & $21 / 11 / 1989$ & 30 & & \\
\hline & & Landsat-2/MSS & $18 / 03 / 1976$ & 60 & & \\
\hline \multirow[t]{2}{*}{2} & \multirow[t]{2}{*}{$\begin{array}{l}\text { Remote } \\
\text { Sensing }\end{array}$} & $\begin{array}{l}\text { Landsat- } \\
\text { 8/ ETM+ }\end{array}$ & $30 / 10 / 2018$ & 30 & $\begin{array}{l}\text { Natioal Remote Sensing } \\
\text { Centre }\end{array}$ & LULC \\
\hline & & Digital globe & 2018 & 1 & Google earth imagery & LULC \\
\hline 3 & $\begin{array}{l}\text { Remote } \\
\text { Sensing }\end{array}$ & SRTM & 2011 & 90 & www.earthexplorer.usgs.gov & DEM \\
\hline 4 & Map & Toposheet & 1979 & 1:50000 scale & Survey of India & DEM \\
\hline 5 & Insitu & Hand held GPS & 2016 & $+/-3$ & NCSCM & $\begin{array}{l}\text { Field } \\
\text { survey }\end{array}$ \\
\hline
\end{tabular}

Table 2 Shoreline change statistics using different statistical methods

\begin{tabular}{|c|c|c|c|c|c|c|c|c|c|c|c|}
\hline \multirow[t]{2}{*}{ Method } & \multirow[t]{2}{*}{ Period } & \multirow{2}{*}{$\begin{array}{l}\text { Mean } \\
\text { Shoreline } \\
\text { Change } \\
\text { (m/year) }\end{array}$} & \multicolumn{4}{|c|}{ Erosion } & \multicolumn{4}{|c|}{ Accretion } & \multirow{2}{*}{$\begin{array}{l}\text { Stable } \\
\%\end{array}$} \\
\hline & & & $\%$ & $\begin{array}{l}\text { Max } \\
\text { (m/year) }\end{array}$ & $\begin{array}{l}\text { Min } \\
\text { (m/year) }\end{array}$ & $\begin{array}{l}\text { Mean } \\
\text { (m/year) }\end{array}$ & $\%$ & $\begin{array}{l}\text { Max } \\
\text { (m/year) }\end{array}$ & $\begin{array}{l}\text { Min } \\
\text { (m/year) }\end{array}$ & $\begin{array}{l}\text { Mean } \\
\text { (m/year) }\end{array}$ & \\
\hline \multirow[t]{3}{*}{ EPR } & $\begin{array}{l}1976- \\
2004\end{array}$ & -0.27 & 30.35 & -8.8 & -1.01 & -2.89 & 24.2 & 7.78 & 1.01 & 2.42 & 45.45 \\
\hline & $\begin{array}{l}2004- \\
2005\end{array}$ & 97.87 & 27.6 & -232.2 & -1.01 & -34.46 & 68.9 & 900.1 & 1.02 & 155.9 & 3.5 \\
\hline & $\begin{array}{l}2005- \\
2018\end{array}$ & 0.90 & 24.6 & $\begin{array}{l}-17.56 \\
\end{array}$ & -1.01 & -3.72 & 42.6 & 60.96 & 1.01 & 4.24 & 32.8 \\
\hline LRR & $\begin{array}{l}1976- \\
2018\end{array}$ & 2.64 & 12.9 & -5.53 & -1.02 & -2.63 & 58.3 & 23.86 & 1.01 & 5.10 & 28.8 \\
\hline WLR & $\begin{array}{l}1976- \\
2018\end{array}$ & 3.36 & 9.9 & -4.22 & -1.01 & -2.19 & 60.3 & 30.06 & 1.01 & 5.92 & 29.8 \\
\hline
\end{tabular}

Please see the supplementary files section to view Table 3.

Table 4 Extent of inundation (ha) in various LULC categories 


\begin{tabular}{|c|c|c|c|c|c|c|c|c|c|}
\hline $\begin{array}{l}\text { S. } \\
\text { No }\end{array}$ & LULC Class & \begin{tabular}{|l} 
Area in \\
2018 (ha)
\end{tabular} & $\begin{array}{l}\% \text { of } \\
\text { area in } \\
2018\end{array}$ & $\begin{array}{l}\text { Area of } \\
\text { inundation } \\
\text { at } 1 \mathrm{~m} \text { SLR } \\
\text { (ha) }\end{array}$ & $\begin{array}{l}\% \text { of } \\
\text { inundation } \\
\text { at } 1 \mathrm{~m} \text { SLR }\end{array}$ & $\begin{array}{l}\text { Area of } \\
\text { inundation } \\
\text { at } 3 \mathrm{~m} \text { SLR } \\
\text { (ha) } \\
\end{array}$ & $\begin{array}{lr}\% & \text { of } \\
\text { inundation } \\
\text { at } \quad 3 \mathrm{~m} \\
\text { SLR } \\
\end{array}$ & $\begin{array}{l}\text { Area of } \\
\text { inundation } \\
\text { at } 5 \mathrm{~m} \text { SLR } \\
\text { (ha) } \\
\end{array}$ & $\begin{array}{l}\% \% \text { of } \\
\text { inundation } \\
\text { at } 5 \mathrm{~m} \text { SLR }\end{array}$ \\
\hline 1 & $\begin{array}{l}\text { Degraded } \\
\text { forest }\end{array}$ & 443.81 & 0.61 & 192.71 & 43.42 & 291.67 & 65.72 & 336.64 & 75.85 \\
\hline 2 & \begin{tabular}{|l} 
Degraded \\
mangroves
\end{tabular} & 196.63 & 0.27 & NA & - & NA & - & NA & - \\
\hline 3 & $\begin{array}{l}\text { Exposed } \\
\text { rock/reef }\end{array}$ & 401.73 & 0.55 & NA & - & NA & - & NA & - \\
\hline 4 & Jetty & 4.05 & 0.01 & NA & - & NA & - & NA & - \\
\hline 5 & Mangroves & 3933.43 & 5.36 & NA & - & NA & - & NA & - \\
\hline 6 & Plantation & 2111.31 & 2.88 & 1.72 & 0.08 & 8.25 & 0.39 & 29.19 & 1.38 \\
\hline 7 & $\begin{array}{l}\text { Reserve } \\
\text { forest }\end{array}$ & 58414.28 & 79.64 & 831.91 & 1.42 & 1696.99 & 2.90 & 2576.10 & 4.41 \\
\hline 8 & Reservoir & 75.51 & 0.10 & 0 & 0 & 0 & 0 & 0 & 0 \\
\hline 9 & Sandy beach & 351.91 & 0.48 & NA & - & NA & - & NA & - \\
\hline 10 & Scrub land & 173.06 & 0.23 & 5.7 & 3.29 & 14.2 & 8.2 & 23.40 & 13.5 \\
\hline 11 & \begin{tabular}{|l} 
Settlement \\
with \\
Vegetation \\
\end{tabular} & 3220.60 & 4.39 & 10.72 & 0.33 & 37.98 & 1.18 & 72.38 & 2.25 \\
\hline 12 & $\begin{array}{l}\text { Submerged } \\
\text { rock/coral } \\
\text { reef } \\
\end{array}$ & 3621.29 & 4.93 & NA & - & NA & - & NA & - \\
\hline 13 & Water body & 392.69 & 0.53 & $\mathrm{NA}$ & - & NA & - & NA & - \\
\hline & Total & 73340.3 & & 1042.76 & - & 2049.09 & - & 3077.71 & - \\
\hline
\end{tabular}

(Note: NA - Not Applicable because it is located in the Inter-tidal Zone)

\section{Figures}

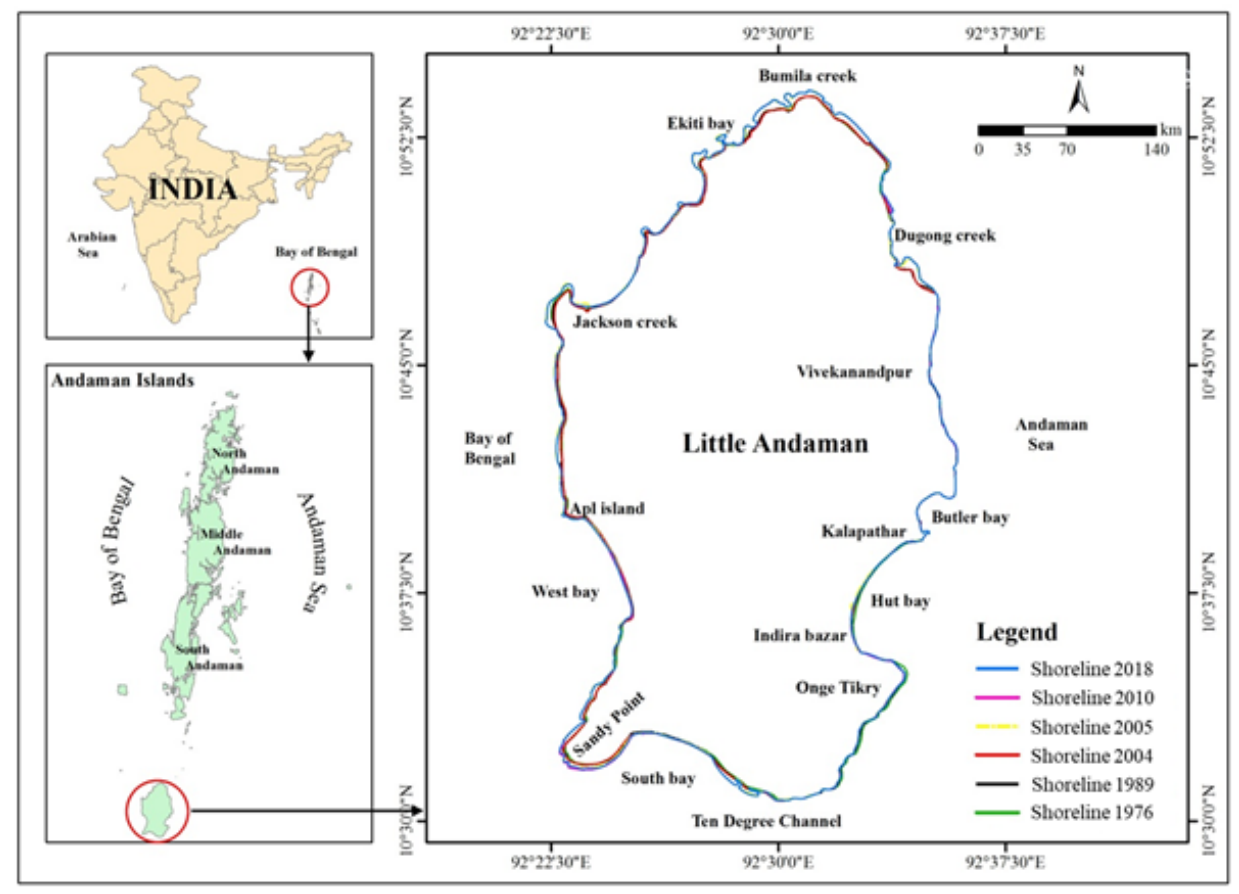

Page $17 / 22$ 
Figure 1

Different shoreline positions in the study area. Note: The designations employed and the presentation of the material on this map do not imply the expression of any opinion whatsoever on the part of Research Square concerning the legal status of any country, territory, city or area or of its authorities, or concerning the delimitation of its frontiers or boundaries. This map has been provided by the authors.

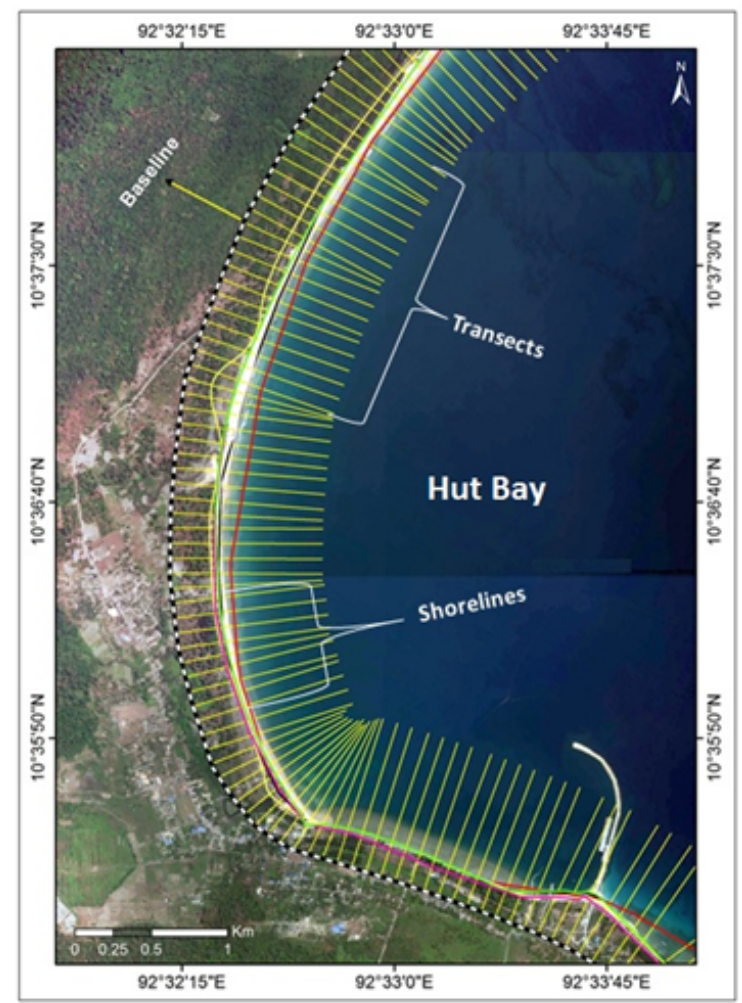

\section{Figure 2}

Baseline, transects and different shoreline constructed along Hut Bay
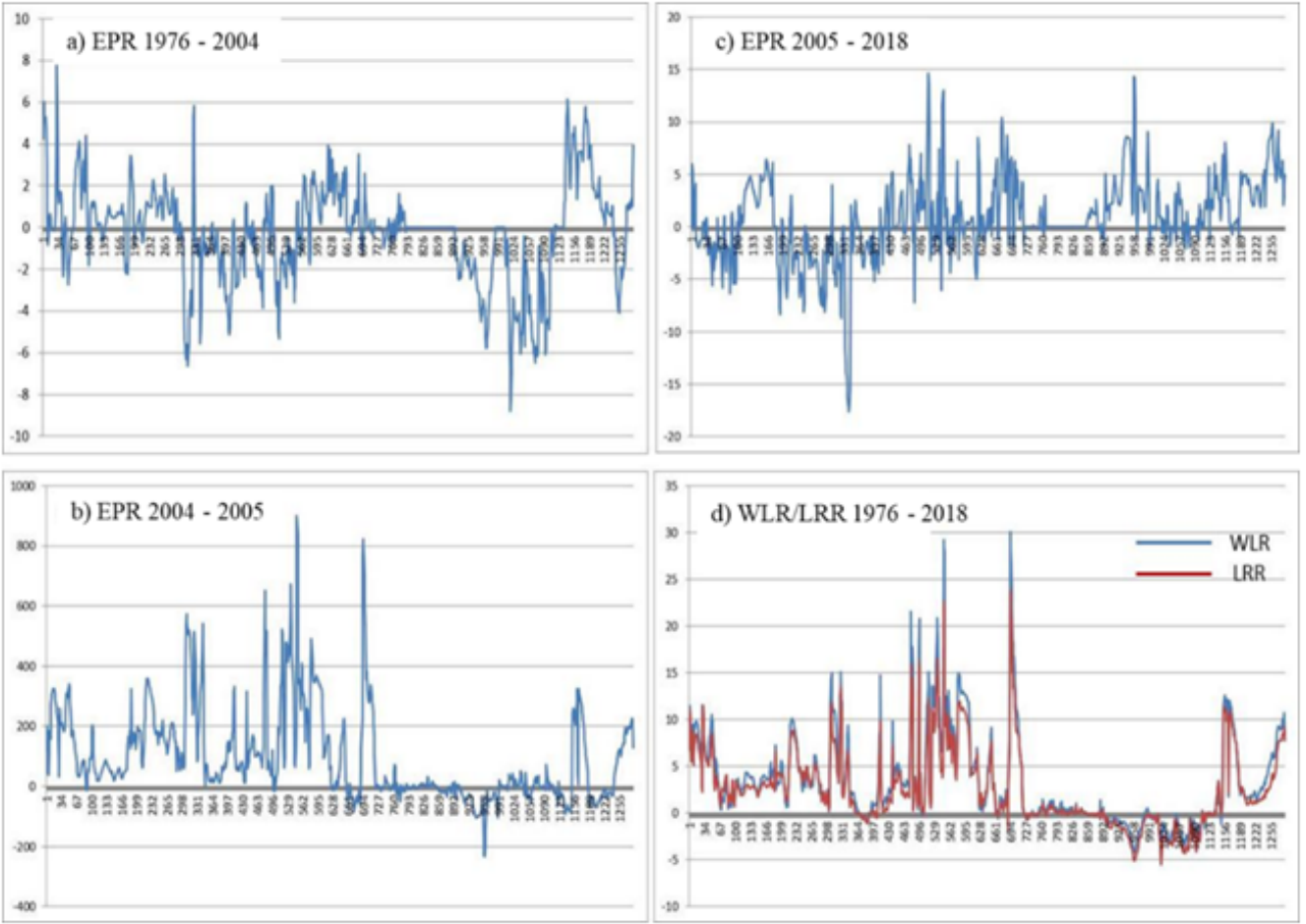


\section{Figure 3}

Graphical representation of shoreline change rate. (a) EPR: 1976-2004 (b) EPR: 2004- 2005 (c) EPR: 2005-2018 (d) WLR \& LRR: 19762018.
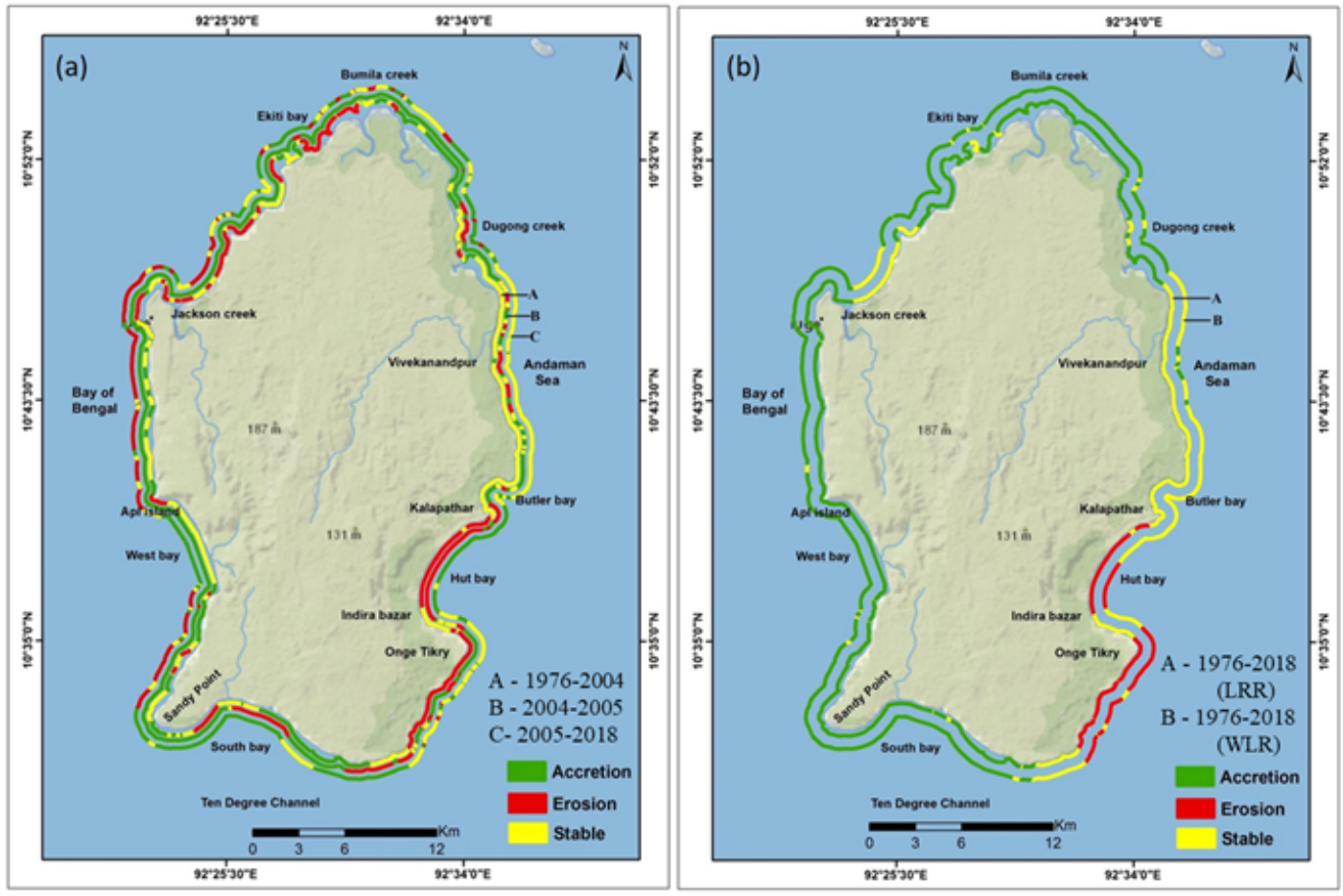

\section{Figure 4}

(a) Short-term shoreline change status (b) Long-term shoreline change status. Note: The designations employed and the presentation of the material on this map do not imply the expression of any opinion whatsoever on the part of Research Square concerning the legal status of any country, territory, city or area or of its authorities, or concerning the delimitation of its frontiers or boundaries. This map has been provided by the authors.

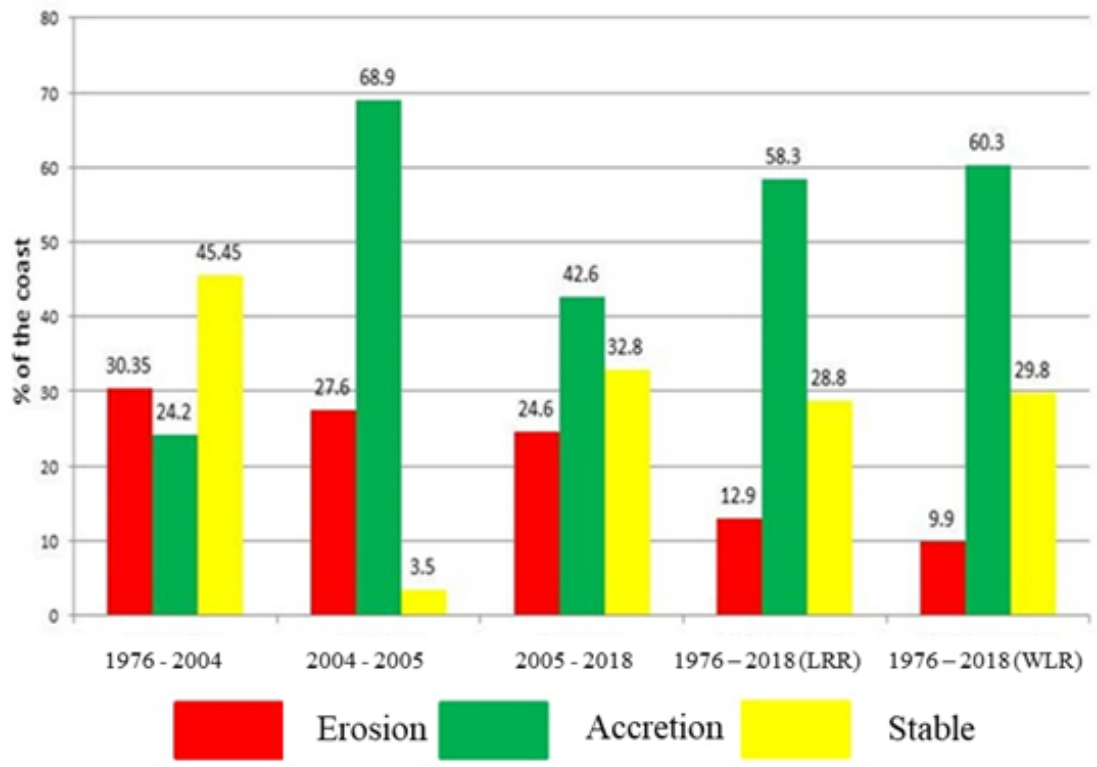

Figure 5

Statistics of shoreline change status in different periods 


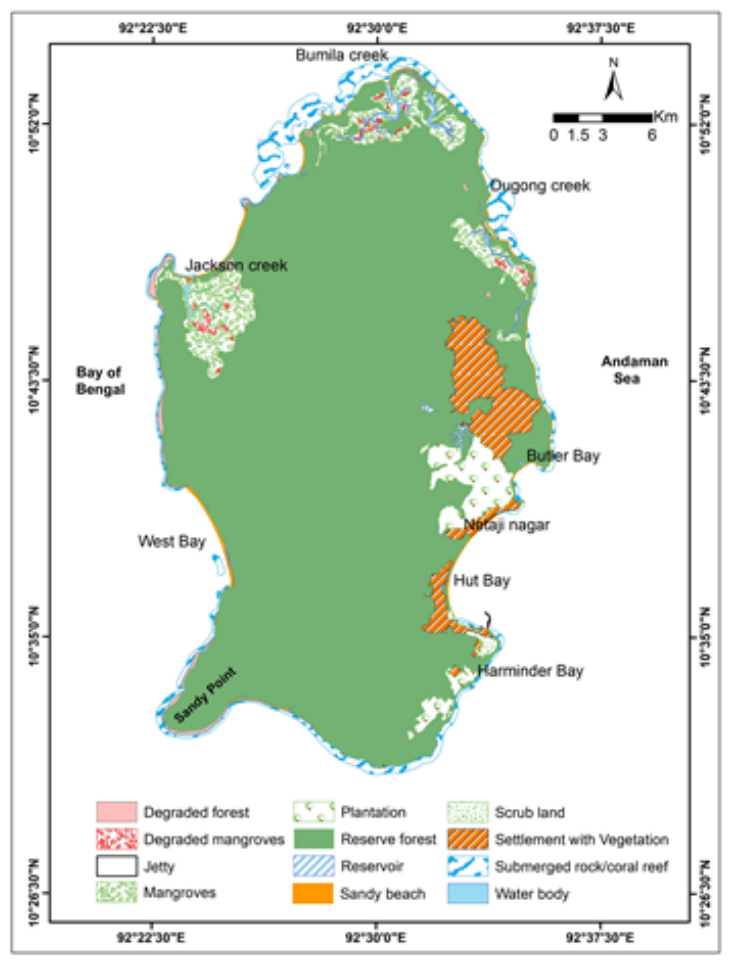

\section{Figure 6}

Landuse/Land cover map. Note: The designations employed and the presentation of the material on this map do not imply the expression of any opinion whatsoever on the part of Research Square concerning the legal status of any country, territory, city or area or of its authorities, or concerning the delimitation of its frontiers or boundaries. This map has been provided by the authors.

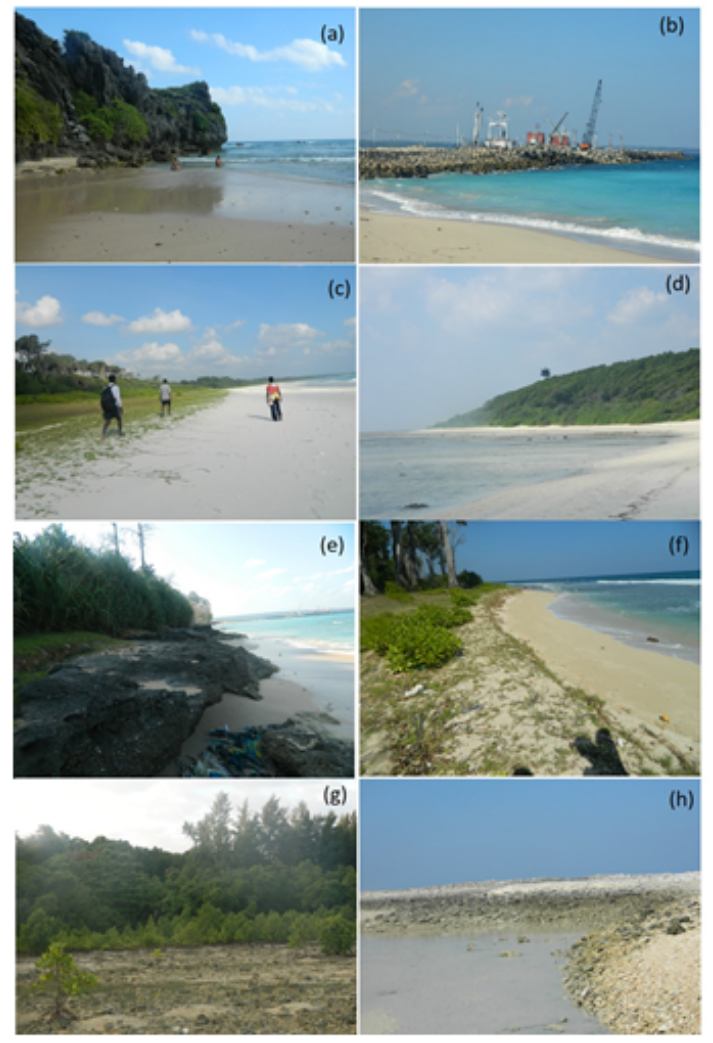

\section{Figure 7}


Field photographs. (a) cliff in Netaji nagar (b) Hut Bay jetty (c) beach view north of Hut Bay (d) cosatal forest in the southern tip (e) beach view south of Hut Bay jetty (f) eroding site in Harminder Bay (g) mangroves in Dugong creek (h) coral debris near Bumila creek

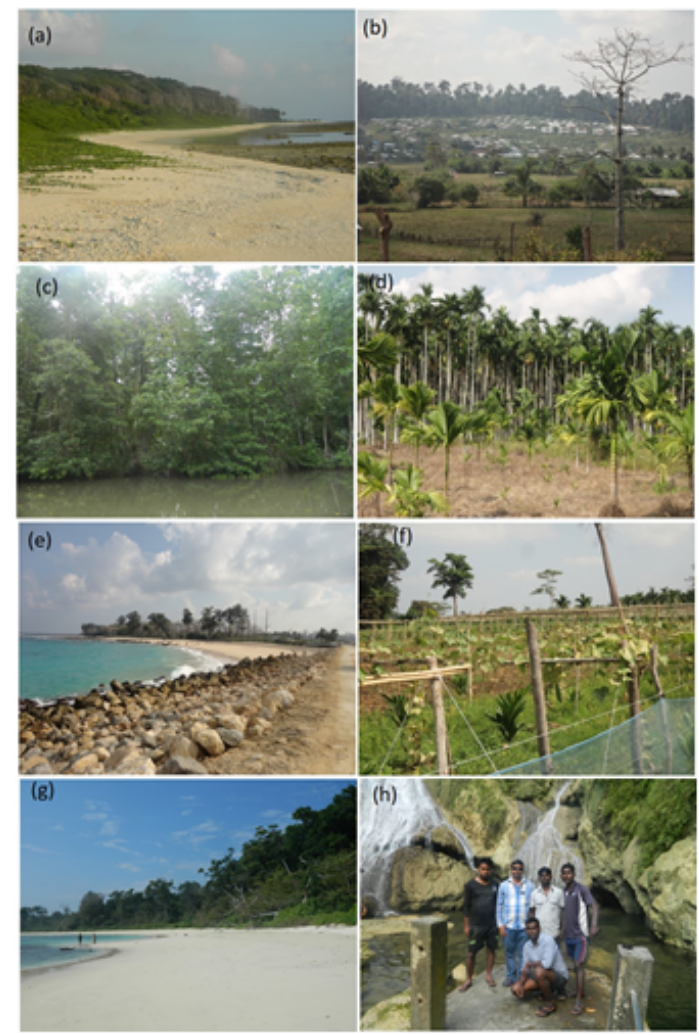

\section{Figure 8}

Field photographs. (a) coastal forest and exposed rocks during low tide (b) tsunami rehabilation area in Hut Bay (c) mangroves in Bumila creek (d) arecac nut plantation (e) jetty area (f) agricultural activity (g) Butler Bay beach (h) White Surf waterfalls

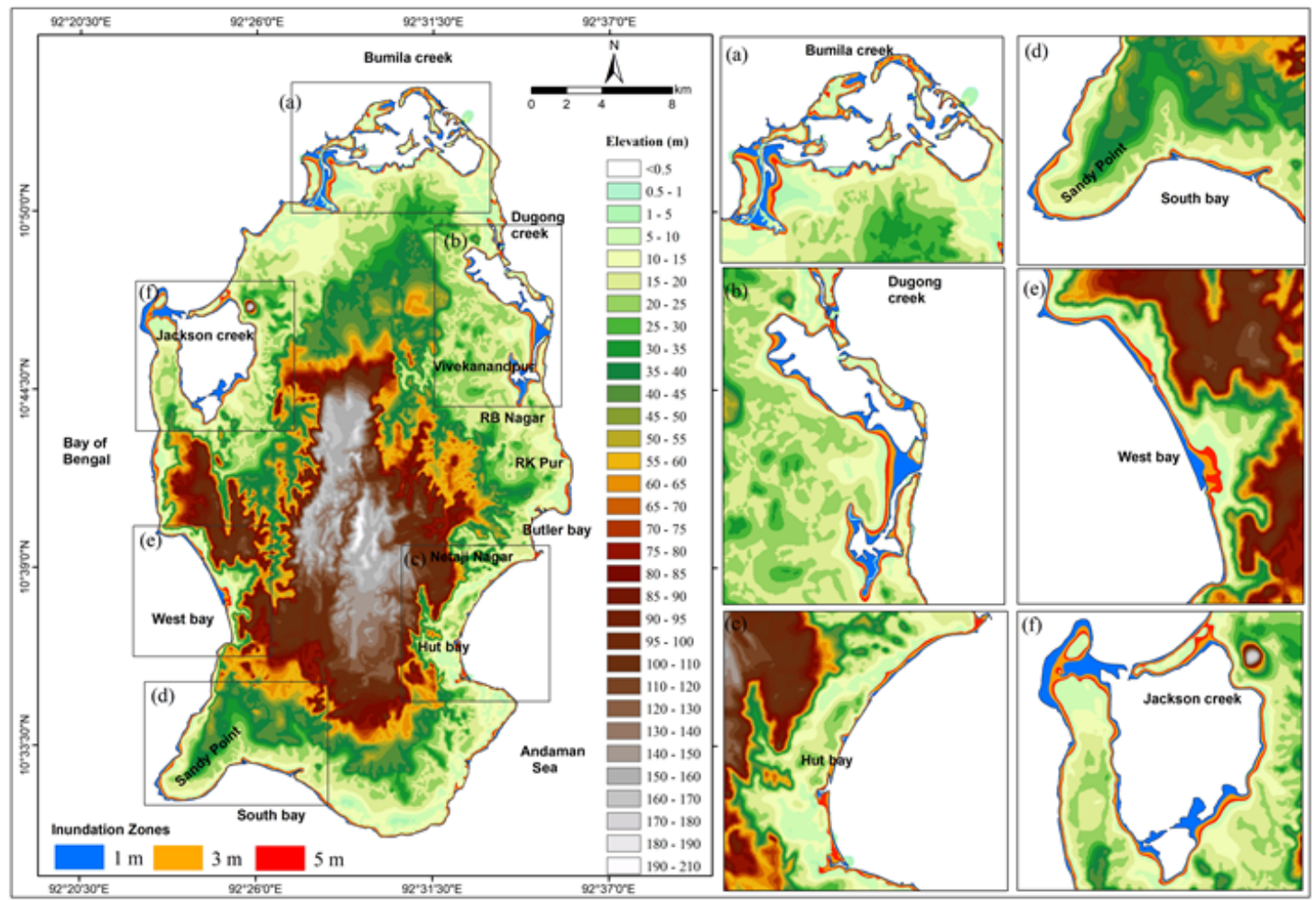

Figure 9 
Elevation and inundation zones of the study area. Note: The designations employed and the presentation of the material on this map do not imply the expression of any opinion whatsoever on the part of Research Square concerning the legal status of any country, territory, city or area or of its authorities, or concerning the delimitation of its frontiers or boundaries. This map has been provided by the authors.

\section{Supplementary Files}

This is a list of supplementary files associated with this preprint. Click to download.

- Table3.docx 